\title{
KNOWLEDGE ECONOMY, ENTREPRENEURIAL ACTIVITY AND CULTURE FACTOR IN MODERN CONDITIONS OF GLOBALIZATION: CHALLENGES FOR GEORGIA
}

\author{
GIVI BEDIANASHVILI \\ Doctor of Economic Sciences, Professor Of European University, \\ Academician of the Academy of Economic Sciences of Georgia, Georgia \\ g.bedianashvili@eu.edu.ge
}

https://doi.org/10.35945/gb.2018.05.004

KEYWORDS: KNOWLEDGE ECONOMY, ENTREPRENEURIAL ACTIVITY, CULTURE AS FACTOR

The modern conditions of globalization and the expected long-term trends set all the countries of the world in front of special challenges. In addition to it, for all the countries having transitional economy it is very important to manage to develop the strong competitive (For innovative potential of the country: Papava 2016, 2018; Bedianashvili 2017b; about the development of export potential and competitiveness: Gaganidze 2015, 2016, 2018; and also for cultural potential: Bedianashvili 2016, 2017a) sides (that are appropriate for their countries) of the social-economic systems and to transform their countries' weak aspects (that make the countries' processes slow down) and to promote to use positive factors in the context of globalization and globalization processes.

In the above-mentioned problems the culture (as the factor), the entrepreneurial activities (as the most important resource of the economic growth of the country) and the systemic presentation of the strategic direction of the formation of the economic knowledge of the country take special places.

The modern stage of globalization is characterized by a number of specific peculiarities of postindustrial development among which, in our opinion, the actualization of the formation of the knowledge-based economics is the most important. It must be mentioned that globalization determines the addition of dimensions with perspectives for knowledge economy such as, for example, resourcetechnological, informational, communicative and institutional structures.

According to the postindustrial theory the main resource of postindustrial economy is information and knowledge. The main type of manufacturing activities is the high level automated production and among the main technologies science-inclusive technologies are used, from the types of economic activities different services become the most spread. If the agriculture field was the determinant in preindustrial society, industry was in industrial society and the theoretical knowledge with the universities (as the place for active generating, getting together and mastering of knowledge) is the determinant.

The above mentioned peculiarities reflect distinctly in such well-known categories as the knowledgeable society, the knowledge society and knowledge-value society. It's important that the core of the society is the knowledge economy while the human capital [Abesadze, 2014; Augier et al., 2007; Hadad, 2017; Foray, 2006; Lopez-Leyva et al., 2017; Skrodzka, 2016; Sundac and Krmpotik, 2011; Tocan, 2012; White et al., 2012] is the main factor of development.

It must be mentioned that in the process of forming the knowledge economy the innovative aspect of entrepreneurial activities is of a particular importance in the context of all business entities. Therefore, the effectiveness of the whole innovative process depends on the efficient functioning of knowledge-based entrepreneurship which, in its own turn, contributes the development and implementation of innovative entrepreneurial policies by the state. Within the innovative entrepreneurial policy the formation of the institutional component, its systematic modernization in dynamics, compliance and synchronization of general formal institutions and business culture as an informal institution should be envisaged.

If we analyze historically the dynamics of the scientific economical idea and the modern conceptions of the phenomenon of entrepreneurship [Baumol, 1990; Blaug, 1989; Veblen, 1904; Drucker, 1993; Simon, 1967; McClelland, 1987; Bedianashvili, 2017; Gvelesiani, 2015; Erkomaishvili, 2016; Svetunkov, 2016; Beugelsdijk, 2017; Hofstede, 2004; Acs at al., 2005] it is distinctly noticeable the adequacy of the above-mentioned regulations in modern conditions and actuality of realization of requirements.

First of all, it must be mentioned that the famous contemporary researcher of the entrepreneurship V.Baumol points out about the great importance of the institutional factor in the entrepreneurial business [Baumol, 1990]. He mentions that the entrepreneurship is the ability of the individual to invent and obtain the new means for the growth of his well-being, power and prestige. He says that the realization of above-mentioned ability is not always directed to creating the additional public product. The rules of the economic activity define the direction of the entrepreneurial ability and this direction can be productive, non-productive or destructive. As Baumol says, according to the "rules of the game", the entrepreneur takes decision how to get the income: by implementing the innovation, by setting up an enterprise and to accomplish his business legally or not, avoid paying taxes or set up illegal business.

We should note that V. Baumol's above-mentioned concept got support not only among the new institutionalism followers but also among the representatives of Oldoliberarist 
school (It must be mentioned that the well-known ideas of $\mathrm{V}$. Oikens about agricultural order are very close to the concepts of V. Baumol).

We consider interesting the technological presentation of economical processes seen from the concept of so called retro-economics that confirms the importance of institutes (the author of the concept "retro-economics" is V. Papava [Papava, 2017]). The author calls retro-economics to such type of economics where technologically lagged behind firms (retro-firms) compared to world modern achievements are functioning but despite there are demands for the products such lagged behind firms produce. [Papava, 2016; 3].

There are different kinds of views about entrepreneurship. For example to R. Cantillon's opinion an entrepreneur is a person who implements the agricultural business in the uncertain conditions and the entrepreneur's income is the present for his risk [Blaug, 2008: 115].

J. Say notes that the entrepreneur implements the coordination of the product factors (land, capital and labor). To his opinion the agriculture business is the fourth factor that complements the effectiveness of the manufacture, and in the society there is always some kind of demand on entrepreneurial business. As it is known, the entrepreneurial ability was discussed as a specific factor only in the XX century, and only afterwards the concept of human capital of the entrepreneur appeared in the science.

T. Veblen points out that the motivation of the entrepreneurial business is to get profit; the source of high profit is the instability in the market and the entrepreneurs always try to create such instability [Veblen, 1904].

In I. Schumpeter's opinion the entrepreneur is a smallholder person who implements innovations in his business; the innovations lead us to losing balance, to blowing up business activities and as a result the economic growth is obtained. To his mind it is not necessary for the entrepreneur to be the owner, the main thing for him is to have ability to implement and use the innovations in his farming business practice, thereto the entrepreneur can't be always the generator of new ideas and innovations, his main task is to use novelties and to get profit with the help of using these novelties [Schumpeter, 1942; 1982].

And we consider important to review the presentation of the entrepreneur, interpreted from the point of psychological science. For example, H. Simon thinks that the entrepreneur's behavior is not always rational and it is not directed to maximization of profitability that is stipulated by the person's psychic abilities, memory and registering abilities and by the really existed limitations connected with the person [Simon, 1967].

For example, D. McClelland considered that the people who implement the producing activities have got specific motivation system, so-called achievement motivation; the later researches, as the author explains, showed that apart from the achievement motivation the entrepreneurs are characterized by the motivation of avoiding failure. The interesting conclusion that the author makes is that the collective motivation of achievements, with the existence of proper mechanisms, in the society provides the economic growth of the given society [McClelland, 1987].

And we consider interesting M. Allais's point of view about entrepreneur business according to which the entrepreneurs can get the universal welfare only in the existence of rival environment that is formed by the social institutions. As the author notes, the state can make laws of institutional limits and change them, but it must be done according to the effectiveness of the economy of market. And exactly this determines the blooming and the dying of the cultures and civilizations [Allais, 1988].

Among the modern researchers we must mark out the famous theoretician of management and innovational economics P. Drucker $\mathrm{He}$ gave the entrepreneurial phenomenon the new conceptual view, according to which the results of entrepreneurs' creative business are reflected not only on economics but on the entire society. As the author notes, in the society of informational era those entrepreneurs who will feel the tendencies of changes in the business and will adapt operatively to these changes will be survived. And those entrepreneurs will become the leaders who will be able to generate of the changes in their business. To P. Drucker's mind the informational society will require the transformations not only in the economic field but abovementioned society will transform the system of education principally and will activate the non-commercial organizations. The intellectuelles who will be able to generate new ideas will be required on the labor market. And those specialists who will be able to implement these ideas will be required as well. Thereto the development of education system is expected to develop towards two directions: 1) preparing the specialists with the knowledge of wide ideology and creative skills and habits; 2) preparing narrow specialists with the profound knowledge of proper profiles [Drucker, 1993].

In modern conditions we can talk over about entrepreneurship by the famous periodic researches in the format of problematic of calculation of entrepreneurial index. As it is known this index is calculated by the Global Entrepreneurship and Development Institute, USA. It completely represents the position of the entrepreneurship in each given country. According to the data prepared for the 2018 Georgia is on the $77^{\text {th }}$ place with the integral indicator (with 26 points) among 137 countries. According to certain indicators towards the USA with the 1st place (with 84 points), Switzerland with the 2 nd place (with 80 points) and Estonia with the $23^{\text {rd }}$ place (with 55.5 points) Georgia's position shows the challenges and problems that must be solved without doubt.

According to the above-mentioned parameters the distance between Georgia and the leading countries of the world shows the approximate distance, at some point, to the desired distance that can be used for benchmarking (while defining the distance in numbers we can use several 


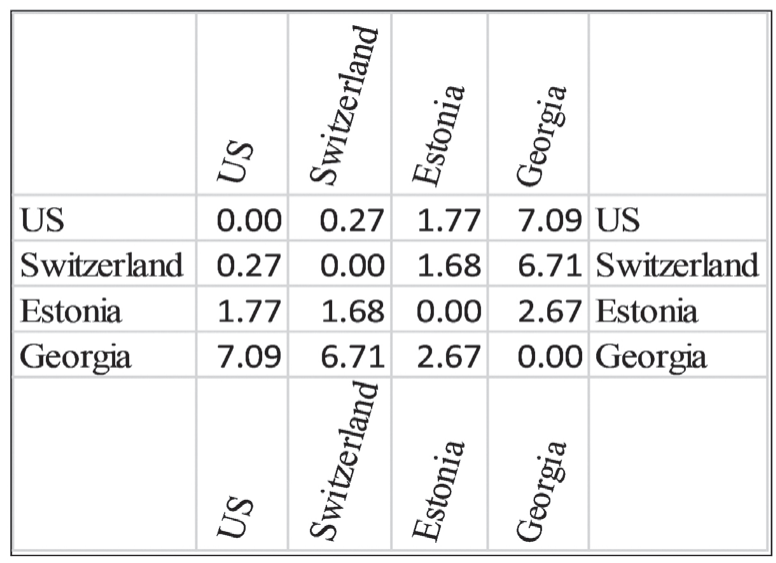

Fig.1 The distance between Georgia and developed countries (calculated according to the materials http://thegedi.org/) according to the global entrepreneurial integral index.

modifications of calculation. For example, here we will use the algorithm: Kogut\&Singh1988). (Fig.1):

Each indicator of above-mentioned characterizes a certain entrepreneurial aspect and answers the proper questions [Acs, et al., 2018]: Pillar1. Opportunity Perception Can the population identify opportunities to start a business and does the institutional environment make it possible to act on those opportunities? Pillar2. Startup Skills Does the population have the skills necessary to start a business based on their own perceptions and the availability of tertiary education? Pillar3. Risk Acceptance Are individuals willing to take the risk of starting a business? Is the environment relatively low risk or do unstable institutions add additional risk to starting a business? Pillar4. Networking Do entrepreneurs know each other and how geographically concentrated are their networks? Pillar5. Cultural Support How does the country view entrepreneurship? Is it easy to choose entrepreneurship or does corruption make entrepreneurship difficult relative to other career paths? Pillar6. Opportunity Perception Are entrepreneurs motivated by opportunity

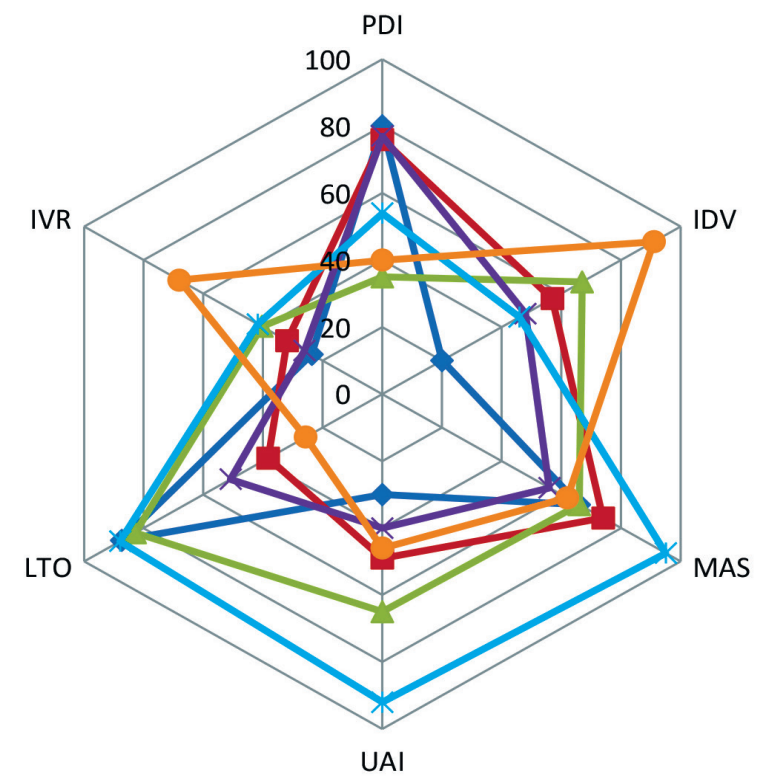

rather than necessity and does governance make the choice to be an entrepreneur easy? Pillar7. Technology Absorption Is the technology sector large and can businesses rapidly absorb new technology? Pillar8. Human Capital Are entrepreneurs highly educated, well trained in business and able to move freely in the labor market? Pillar9. Competition Are entrepreneurs creating unique products and services and able to enter the market with them? Pillar10. Product Innovation Is the country able to develop new products and integrate new technology? Pillar11. Process Innovation Do businesses use new technology and are they able access high quality human capital in STEM fields? Pillar12. High Growth Do businesses intend to grow and have the strategic capacity to achieve this growth? Pillar13. Internationalization Does entrepreneurs want to enter global markets and is the economy complex enough to produce ideas that are valuable globally? Pillar14. Risk Capital Is capital available from both individual and institutional investors?

We think that innovational entrepreneurial policy in Georgia and corresponding arrangements of institutional modernization must be directed to overcoming the above mentioned backwardness. The perfection of business culture (as an informal institute) must be paid attention to. The researches (Hofstede, 2004; Bedianashvili, 2014; Bedianashvili, 2017; Didero et al.,2008; Beugelsdijk, 2007; Furman et al.,2002; Geertz,1973; Herbig and Srholec,1998; Inglehart and Welzel, 2005; James, 2005; Von Hippel, 2005; Acs, 2006; Barnett, 1953; Beugelsdijk et al.,2014; Brons,2006; Dickson et al.,2003; Edler and Fagerberg, 2017; Differences in Innovation Culture Across Europe, 2008) prove that the cultural factor has the decisive importance for developing the entrepreneurial and innovational business. As for the desired position of Georgia, it is necessary to implement the transformation of cultural values in perspective (Fig.2) such as reinforcement of long term orientation (pragmatism), reduction of power distance and development of individual characters (Bedianashvili, 2016).

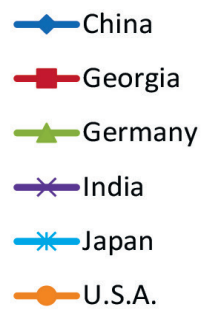

Fig.2.The comparative disposition of cultural values for Georgia according to existed situation 


\section{REFERENCES:}

1. Acs, Z. J., Audretsch, D. B., Braunerhjelm, P. and Carlsson, B., (2005). The Knowledge Spillover Theory of Entrepreneurship, Discussion Papers on Entrepreneurship, Growth and Public Policy, Group Entrepreneurship, Growth and Public Policy, Jena, Germany: Max Planck Institute of Economics.

2. Acs, Z. J., Szerb, L., Lloyd, A., (2018). Global Enterpreneurship Index. Washington, GEDI.

3. Acs, Z.J., (2006). How is Entrepreneurship Good for Economic Growth?, Innovations: Technology, Governance, Globalization 1(1), pp. 97-107.

4. Allais M. 1988. An Outline of My Main Contributions to Economic Science.

https://www.nobelprize.org/nobel_prizes/economic-sciences/laureates/1988/allais-lecture.pdf

5. Àsgeirsdòttir, B., (2006). OECD work on knowledge and the knowledge economy. In Brian, K., and Dominique, F. (Eds.), Advancing knowledge and the knowledge Economy. Cambridge: The MIT press, pp.17-23.

6. Augier, M., and Teece, D.J. (2007). Perspectives on research and development. Organizing and Managing innovation in a (Global) knowledge-basedeconomy. In Ichijo, K., and Nonaka, I. (Eds.), Knowledge creation and management. New Challenges for managers. Oxford: Oxford University Press, pp. 198-212.

7. Barnett, H.G. (1953). Innovation: The basis of cultural change. New York: Mc Graw Hill.

8. Baumol W. J. (1990). Enterpreneurship: Productive, Unproductive and Destructive // Journal of Political Economy. Vol. 98. №5. Pt.1, pp. 893-920.

9. Bedianashvili G. (2016). The Global Business Environment, European Integration and the Cultural Potential of Socialeconomic Development of Georgia. Journal “Globalization and Business”. European University, № 1, pp. 19-25 (In Georgian). 10. Bedianashvili, G., (2014). Culture as an Institution in the Context of Socio-economic Development of Country and International Business. J. "Ekonomisti", No 6. P. 6-16 (In Georgian).

11. Bedianashvili G. (2017a). The Culture as an Informal Institute and the Factor of Social - Economical Development and Business in the Context of European Integration. In book: Conference Proceedings 1 ISCBE'17 Building Bridges Between Business Research and Industry Needs Conference Proceedings. South East European University, Tetovo, Republic of Macedonia.

12. Bedianashvili, G., (2017b). Formation of Knowledge Economy and Innovative Entrepreneurial Policy: Institutional Aspects. Journal: Globalization and Business, no 3, pp.10-16. (In Georgian).

13. Beugelsdijk, S. (2007). 'Entrepreneurial culture, regional innovativeness and economic growth', Journal of Evolutionary Economics, 17(1): pp.187-210.

14. Beugelsdijk, S., Slangen, A., Maseland, R., \& Onrust, M. 2014. The impact of home-host cultural distance on foreign affiliate sales: The moderating role of cultural variation within host countries. Journal of Business Research, 67(8), pp.1638-1646.

15. Blaug, .M. (1989). Great Economists Since Keynes: An Introduction to the Lives and Works of One Hundred Modern Economists.

16. Brons, L. (2006). Indirect measurement of regional culture in the Netherlands, Tijdschrift voor Economische en Sociale Geografie, 97(5): pp.547-566.

17. Dahlstrand, Å. L. and Stevenson, L., (2010). Innovative Entrepreneurship Policy: Linking Innovation and Entrepreneurship in a European Context. Annals of Innovation \& Entrepreneurship, vol.1. Retrieved 08. 09. 2012, from http://www.

innovationandentrepreneurship.net/index.php/aie/article/view/5602/html_34.

18. Dickson, M. W., Den Hartog, D. N., \& Mitchelson, J. K. (2003). Research on leadership in a cross-cultural context: Making progress, and raising new questions. The leadership quarterly, 14(6), pp.729-768.

19. Didero, M., Gareis, K., Marques, P., \& Ratzke, M. (2008). Differences in innovation culture across Europe. Transformative Use of ICT in EU Regions. Transform, Germany.

20. Didero, M., Gareis, K., Marques, P., Ratzke, M. et al. 2008. Differences in Innovation Culture across Europe, Discussion paper, Transform project report.

21. Differences in Innovation Culture Across Europe (2008).

22. Drucker Peter F. (1993). Innovation and Entrepreneurship.

23. Edler J., Fagerberg, J. (2017).-Innovation policy: what, why, and how. Oxford Review of Economic Policy, Volume 33, Number 1, pp. pp.2-23.

24. Erqomaishvili G., (2016). Small Entrepreneurship Supporting Policy in Georgia. World Academy of Science, Engineering and Technology International Journal of Economics and Management Engineering Vol: 10, No: 5, pp.1409-1412.

25. European Innovation Scoreboard (2008). Comparative Analysis of Innovation Performance (2009), Pro Inno Europe paper No 10, http://wwwproinno-europe.eu/publications (retrieved, June 2010).

26. European Union EU. (2012). The Innovation Union Scoreboard. Research and Innovation Union scoreboard, Retrieved 07. 20. 2012, from http://www.proinno-europe.eu/metrics

27. Fagerberg, J. and Srholec, M., 2008. National Innovation Systems, Capabilities and Economic Development, Research Policy 37/9, pp.1417-1435. 
28. Fagerberg, J., Feldman, M., Shorlec, M., (2011). Technological Dynamics and Social Capability: Comparing U.S. States and European Nations, CIRCLE Paper no 11/2011, Lund University.

29. Foray, D., 2006. The economics of knowledge. Cambridge: The MIT Press.

30. Furman, J. L., Porter, M. E., Stern, S. 2002, The Determinants of National Innovative Capacity. Research Policy, 31 (6): 899-933. doi:10.1016/ S0048-7333 (01)00152-4

31. Geertz, C. (1973). The Interpretation of Cultures, New York, Basic Books.

32. Gvelesiani R., (2015). Intrinsic Contradictions of Entrepreneurship Development and Self-development. World Academy of Science, Engineering and Technology International Journal of Economics and Management Engineering Vol: 9, No: 3, pp. 1007-1010.

33. Hadad, S., 2017. Knowledge Economy: Characteristics and Dimensions. Journal: Management Dynamics in the Knowledge Economy Vol.5, no.2, pp.203-225.

34. Hofstede, G et al. (2004). 'Culture's role in entrepreneurship: self-employment out of dissatisfaction', in: Brown, T and Ulijn, J. (eds.) 'Innovation, Entrepreneurship and Culture. The interaction between Technology, Progress and Economic Growth', Cheltenham, Massachusetts: Edward Elgar Publishing, pp. 162-203.

35. Hofstede, G. (2011). Dimensionalizing Cultures: The Hofstede Model in Context. Online Readings in Psychology and Culture, 2(1). https://doi.org/10.9707/2307-0919.1014.

36. Inglehart, R. and Welzel, C. (2005) 'Modernization, Cultural Change, and Democracy: The Human Development Sequence', Cambridge, MA, et al.: Cambridge University Press.

37. Lopez-Leyva, S., Mungaray-Moctezuma A-B., 2017. Knowledge-Based Economy as a Foundation for the Economic Development of Countries. Journal: Management Dynamics in the Knowledge Economy Vol.5 no.4, pp.481-501.

38. McClelland David C. (1987). Human Motivation. Boston University.

39. Meskhia, I., Shaburishvili, S. (2015). Basics of researche of the technological environment of business. Journal: Zeszyty Naukowe Uniwersytetu Przyrodniczo-Humanistycznego w Siedlcach. Seria: Administracja i Zarządzanie (34) 2015, pp. 117-124. 40. Papava V. (2018). Catching up and Falling Behind: the Experience of the Post-Communist Countries of the European Union and Georgia. GFSIS Expert Opinion, No. 70, Tbilisi. GFSIS. http://papava.info/publications/Papava_Catching-Up-orFalling-Behind_Eng.pdf

41. V. Papava, V. (2016). Technological Backwardness - Global Reality and Expected Challenges for the World's Economy. GFSIS Expert Opinion, No. 70, Tbilisi: GFSIS.

42. Papava V. (2017). Retroeconomics - Moving from Dying to Brisk Economy. Journal of Reviews on Global Economics, 6 , 455-462. http://www.lifescienceglobal.com/home/cart?view=product\&id=2567

43. Gaganidze G. "Foreign Trade of Georgia, Moldova and the Ukraine with the European Union after Signing the Association Agreement" Ecoforum 7 (N1, 2018)

44. Gaganidze G. (2016). "Georgian Export Potential Utilization on the EU Market”; Journal of International Management Studies. 2016, Vol. 16 Issue 1, p13-18. 6p.

45. Gaganidze, G. (2015). "Competitive advantages of Georgian non-agricultural products on the EU market" The Business \& Management Review; London Vol. 6, Iss. 1: 26-30. London: The Academy of Business and Retail Management (ABRM). (Feb 2015) 46. Rooka, D., Salvatorip, A., Moylandb, J., Rosab, P., 2017. Innovation Patterns: Upgrading Sectorial Classification for the Fourth Industrial Revolution. Kensho Technologies.

47. Schumpeter J. A. (2012). The Theory of Economic Development (An Inquiry into Profits, Capital, Credit, Interest, and the Business Cycle). New Brunswick: Transaction Publishers.

48. Schumpeter, J. (1942). Capitalism, Socialism, and Democracy (1st ed.). Harper and Brothers.

49. Simon Herbert A. (1967). Theories of Decision-Making in Economics and Behavioral Science. Journal: Organizational Decision Making. Prentice Hall, New-Jersey. pp. 201-222.

50. Skrodzka, I. (2016). Knowledge-based economy in the European Union - Crosscountry analysis. Statistics in Transition New Series, 17(2), pp.281-294.

51. Sundać, D., and Krmpotić, I.F. (2011). Knowledge economy factors and the development of knowledge-based economy. Croatia Economic Survey, 13(1), pp.105-141.

52. Svetunkov, M. Svetunkov, S. (2010). Entrepreneurship and Innovations. (In Russian)

53. Tocan, M.C. 2012. Knowledge based economy assessment. Knowledge Management. Retrieved from http://www. scientificpapers.org/knowledgemanagement/knowledge-based-economy-assessment/.

54. Veblen, T. 1904. Theory of Business Enterprise.

http://www.businessbuildersbanquet.com/software/veblen2.pdf

55. Kogut B., Singh, H. (1988). The Effect of National Culture on the Choice of Entry Mode. Journal of International Business Studies. V. 19, Issue 3, pp. 411-432. 


\section{KNOWLEDGE ECONOMY, ENTREPRENEURIAL ACTIVITY AND CULTURE FACTOR IN MODERN CONDITIONS OF GLOBALIZATION: CHALLENGES FOR GEORGIA}

GIVI BEDIANASHVILI

https://doi.org/10.35945/gb.2018.05.004

Doctor of Economic Sciences, Professor Of European University,

Academician of the Academy of Economic Sciences of Georgia, Georgia

g.bedianashvili@eu.edu.ge

KEYWORDS: KNOWLEDGE ECONOMY, ENTREPRENEURIAL ACTIVITY, CULTURE AS FACTOR

\section{SUMMARY}

The modern conditions of globalization and the expected long-term trends set all the countries of the world in front of special challenges. In addition to it, for all the countries having transitional economy it is very important to manage to develop the strong competitive of the social-economic systems and to transform their countries' weak aspects (that make the countries' processes slow down) and to promote to use positive factors in the context of globalization and globalization processes.
In the above-mentioned problems the culture (as the factor), the entrepreneurial activities (as the most important resource of the economic growth of the country) and the systemic presentation of the strategic direction of the formation of the economic knowledge of the country take special places. In the paper the main directions of setting the above-mentioned issues and solving these issues are given on Georgia's example. 